АИНАМИКА ПОПУЛЯЦИЙ АЕРЕВЬЕВ И ГОРИЗОНТАЛЬНОЙ СТРУКТУРЫ СТАРОВОЗРАСТНОГО НЕМОРАЛЬНОГО ШИРОКОЛИСТВЕННОГО ЛЕСА С АОМИНИРОВАНИЕМ QUERCUS ROBUR И TILIA CORDATA (ПO РЕЗУЛЬTATAM МНОГОЛЕТНЕГО МОНИТОРИНГА, ПЕНЗЕНСКАЯ ОБЛАСТЬ)

\author{
А. А. Чистякова \\ Пензенский государственный университет, \\ Россия, 440026, г. Пенза, ул. Красная, 40 \\ E-mail: bio@pnzgu.ru
}

\title{
DYNAMIC OF TREE POPULATIONS AND HORIZONTAL STRUCTURE OF THE OLD-GROWTH NEMORAL HERB BROAD-LEAVED FOREST WITH DOMINATION OF QUERCUS ROBUR AND TILIA CORDATA (ACCORDING TO THE RESULTS OF LONG-TERM MONITORING, PENZA REGION)
}

\author{
A. A. Chistyakova \\ Penza State University, \\ 40 Krasnaya street, Penza, 440026, Russia \\ E-mail: bio@pnzgu.ru
}

Аннотация. Дается прогноз развития старовозрастного дубо-липняка в Инзельском лесном массиве (Пензенская область). По эколого-флористической классификации сообщество относится к ассоциации Mercurialo perrenis-Quercetum roboris Bulokhov et Solomeshch 2003. В основу прогнозов легли длительные мониторинговые наблюдения (28 лет) на постоянной пробной площади. Проанализировано состояние ценопопуляций деревьев и составлены карты размещения биогрупп деревьев разного возраста. Исследование показало, что существующая горизонтальная структура (мозаичность) исследуемого сообщества обеспечивает надежное развитие только теневыносливых видов (Acer platanoides, Tilia cordata, Fraxinus excelsior, Ulmus glabra). Для видов, требовательных к свету (Quercus robur, Populus tremula), имеющаяся световая мозаика недостаточна для развития. Малочисленность популяции дуба и гибель его подроста делают положение этого вида в современных сообществах весьма уязвимым. Неполнота видового состава деревьев и невозможность его восстановления при существующей структуре сообщества позволяют охарактеризовать рассматриваемый дубо-липняк как квазиклимаксовый, трансформация которого в климаксовый невозможна без вмешательства человека. Уменьшение размеров возрастной мозаичности препятствует формированию в будущем полночленных популяций всех потенциальных ценозообразователей.

Ключевые слова: старый широколиственный лес, ценопопуляционный мониторинг, прогноз развития сообществ, климакс, Quercus robur.

Аля цитирования: Чистякова, А. А. Динамика популяций деревьев и горизонтальной структуры старовозрастного неморального широколиственного леса с доминированием QUERCUS ROBUR и TILIA CORDATA (по результатам многолетнего мониторинга, Пензенская область) / А. А. Чистякова // Russian Journal of Ecosystem Ecology. - 2017. - Vol. 2 (4). https://doi.org/10.21685/2500-0578-2017-4-5

Abstract. A forecast for the development of old-growth nemoral herb broad-leaved forest with domination of Quercus robur and Tilia cordata in the Inselsky forest range (the Penza region) is given in the article. The community belongs to the association Mercurialo perrenis-Quercetum roboris Bulokhov et Solomeshch 2003 according the Braun-Blanquet floristic classification. Long-term monitoring observations (28 years) on a permanent sample plot were the basis of the forecasts. The ontogenetic state of tree species coenopopulations was analyzed and maps were produced for placing biogroups of trees of different age. The study showed that the existing horizontal structure (mosaic) of the studied community ensures the reliable development of only shade-tolerant species (Acer platanoides, Tilia cordata, Fraxinus excelsior, Ulmus glabra). The available light regime is not sufficient for development of light-demanding species (Quercus robur, Populus tremula). The small number of oak individuals in 
the population and the death of its undergrowth make the position of Quercus robur very vulnerable in modern communities. The incompleteness of tree species composition and the inability to restore it with the existing structure of the community make it possible to characterize the broad-leaved forest as a quasi-climax. The transformation of this forest into the climax is impossible without human intervention. Reducing size of mosaic prevents the formation of uneven-aged populations of all potential tree species in the future.

Key words: old-growth broad-leaved forest, population monitoring, forecast of community development, climax, Quercus robur.

For citation: Chistyakova A.A. Dynamic of tree populations and horizontal structure of the old-growth nemoral herb broad-leaved forest with domination of QUERCUS ROBUR and TILIA CORDATA (according to the results of long-term monitoring, Penza region). Russian Journal of Ecosystem Ecology. 2017;2(4). (In Russ.). Available from: https://doi.org/10.21685/2500-0578-2017-4-5

\section{Введение}

Оценка состояния популяций растений позволяет прогнозировать их дальнейшее развитие [1-5]. Однако длительный мониторинг постоянных пробных площадей помимо этого обеспечивает не только прямое считывание динамически меняющейся информации, но и возможность корректировать прогнозы развития ценозов [6-8]. Задача статьи - на основе многолетнего мониторинга дать прогноз развития старовозрастного широколиственного леса на примере одного из лесных массивов Пензенской области.

\section{Район, объекты и методы исследования}

В 1976 г. в водораздельном старовозрастном дубо-липняке Инзенского лесного массива была заложена постоянная мониторинговая площадь размером 1 га. По эколого-флористической классификации сообщество относится к ассоциации Mercurialo perrenis-Quercetum roboris Bulokhov et Solomeshch 2003 [9]. В травяном покрове сообщества преобладали Carex pilosa Scop. и Aegopodium podagraria L., а возраст самых старых деревьев составлял 200-220 лет. Исследуемый ценоз - часть лесной территории правобережной водоохраняемой зоны реки Суры и находится на северо-востоке Пензенской области близ границ с Мордовией и Ульяновской областью (Кенчурское лесничество, кв. 104; бывшее Сурское лесничество, кв. 24). За годы мониторинга (1976-2001) мы трижды с интервалом в 13 и 12 лет провели полный пересчет всех особей деревьев с указанием их биологического и календарного возрастов, жизненности, происхождения, размеров и дважды (в 1989 и 2001) осуществили картирование постоянной площади. На картах отмечали проекции крон и стволов всех деревьев диаметром 4 см и более, контуры скоплений молодых особей, а также кустарников и микроассоциаций трав. Абсолютный возраст деревьев определяли на моделях возрастным буром или по спилам на пнях с близлежащих вырубок. Биологический возраст (онтогенетическое состояние) деревьев оценивали по ранее разработанным методикам [10-12]. Для обозначения онтогенетических состояний использовались следующие индексы: $v$ - виргинильное, $g_{1}$ - молодое генеративное, $g_{2}$ - средневозрастное генеративное, $g_{3}$ - старое генеративное, $\mathrm{s}$ - сенильное. Мы проиндексировали возраст каждого дерева и получили карты возрастной мозаичности насаждения, так как деревья одного класса возраста (20 лет) образуют разные по размерам скопления - возрастные биогруппы - одно- или многовидовые (рис. 1, 2).

\section{Результаты и обсуждение}

В представленной работе анализируются данные 1976, 1989 и 2001 гг. За период наблюдений насаждение сохранило свойственные ему вертикальную и горизонтальную структуры. Верхний ярус во все годы наблюдений образовывали Quercus robur L., Fraxinus excelsior L., Tilia cordata Mill., Acer platanoides L., Ulumus glabra Huds., но соотношение между ними не оставалось постоянным. В 1976 г. оно было представлено формулой 1(Д+Яс)7Лп2Ко, ед. В. Bo II-м и III-ем ярусах усиливалось участие этих же видов, исключая Quercus robur. В подлеске встречались Populus tremula L. и Sorbus aucuparia L. Дуб, помимо первого яруса, имелся единично в подросте, но высота его не превышала 1,5 м.

К 1989 г. в результате ветровала (1980) выпали старые деревья ясеня диаметром 60-66 см, многие особи клена остролистного, вяза, некоторые липы, и в целом I-й ярус стал характеризоваться формулой 1(Д+В)7Лп2Ко. Ясень сохранился во II-м и III-ем ярусах. С 1976 по 1989 г. наиболее существенные изменения произошли в численности молодых $\left(\mathrm{im}_{1}, \mathrm{im}\right)$ особей: она почти в 3 раза уменьшилась у липы, в 25 раз - у осины, незначительно - у рябины (со 132 до 112 шт./га), немного возросла у дуба (с 7 до 10), ясеня (с 817 до 852), клена остролистного (с 414 до 482) и вяза (с 557 до 591) (табл. 1). В то же время общая плотность взрослых растений всех видов не только за истекшие 13 лет, 
но и за весь 25-летний срок изменилась мало (687, 707, 806 шт./га соответственно, см. табл. 1), и видимо она-то и соответствует экологической емкости экотопа. Доля особей хорошей жизненности в популяциях деревьев удерживалась примерно на одном уровне: у липы она соответственно составляла 41,4 и 41,8 \%; у ясеня -
84,0 и 84,1 \%; клена - 45,5 и 48,4 \%; вяза 47,2 и 46,6 \%; дуба - 63,3 и 50,0 \%. Жизненность заметно снизилась только у осины (с 87,1 \% до полного отсутствия растений хорошей жизненности) и рябины (с 95,5 до 20,9 \%) (см. табл. 1).

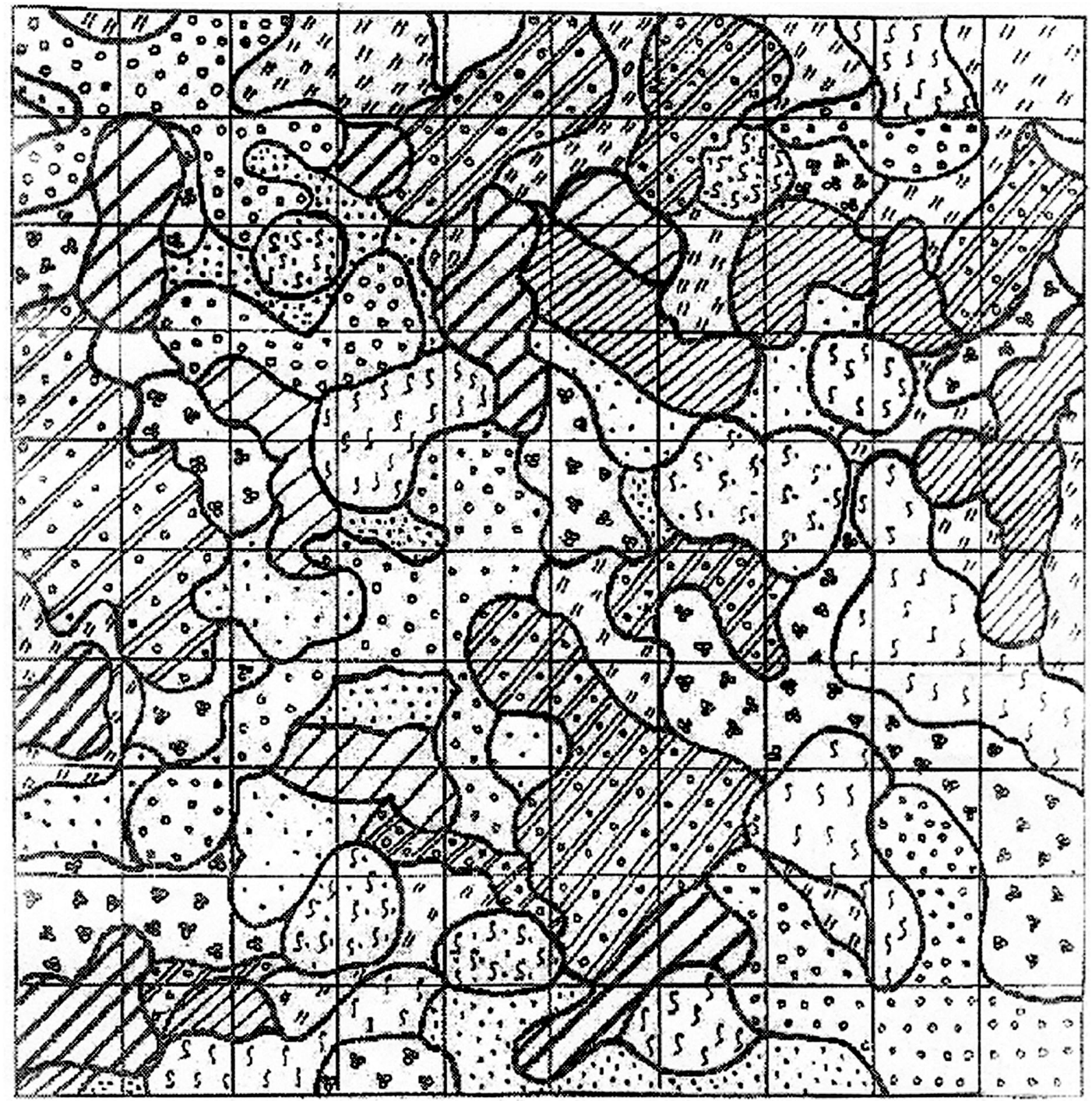

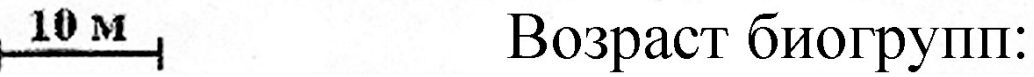

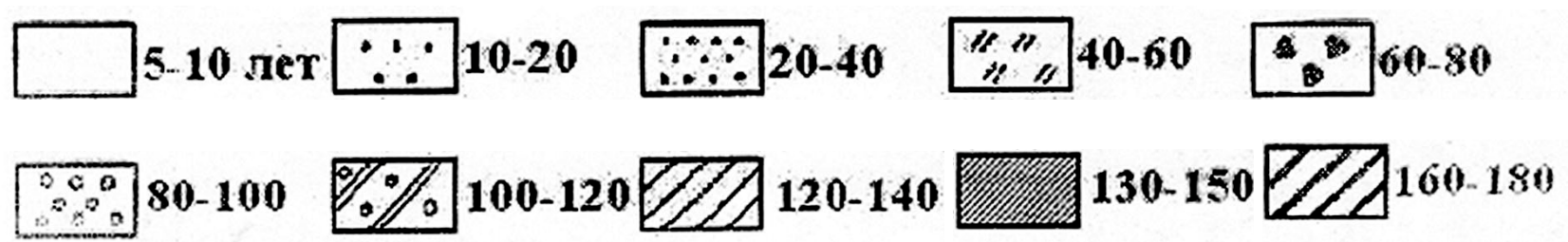

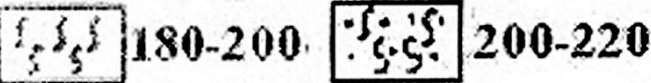

Рис. 1. Возрастная мозаичность неморального широколиственного леса с доминированием Quercus robur и Tilia cordata (по результатам картирования 1989 г.)

Fig. 1. Mosaic of biogroups of multiple-aged trees in nemoral herb broad-leaved forest with domination of Quercus robur and Tilia cordata (according to the results of mapping in 1989) 


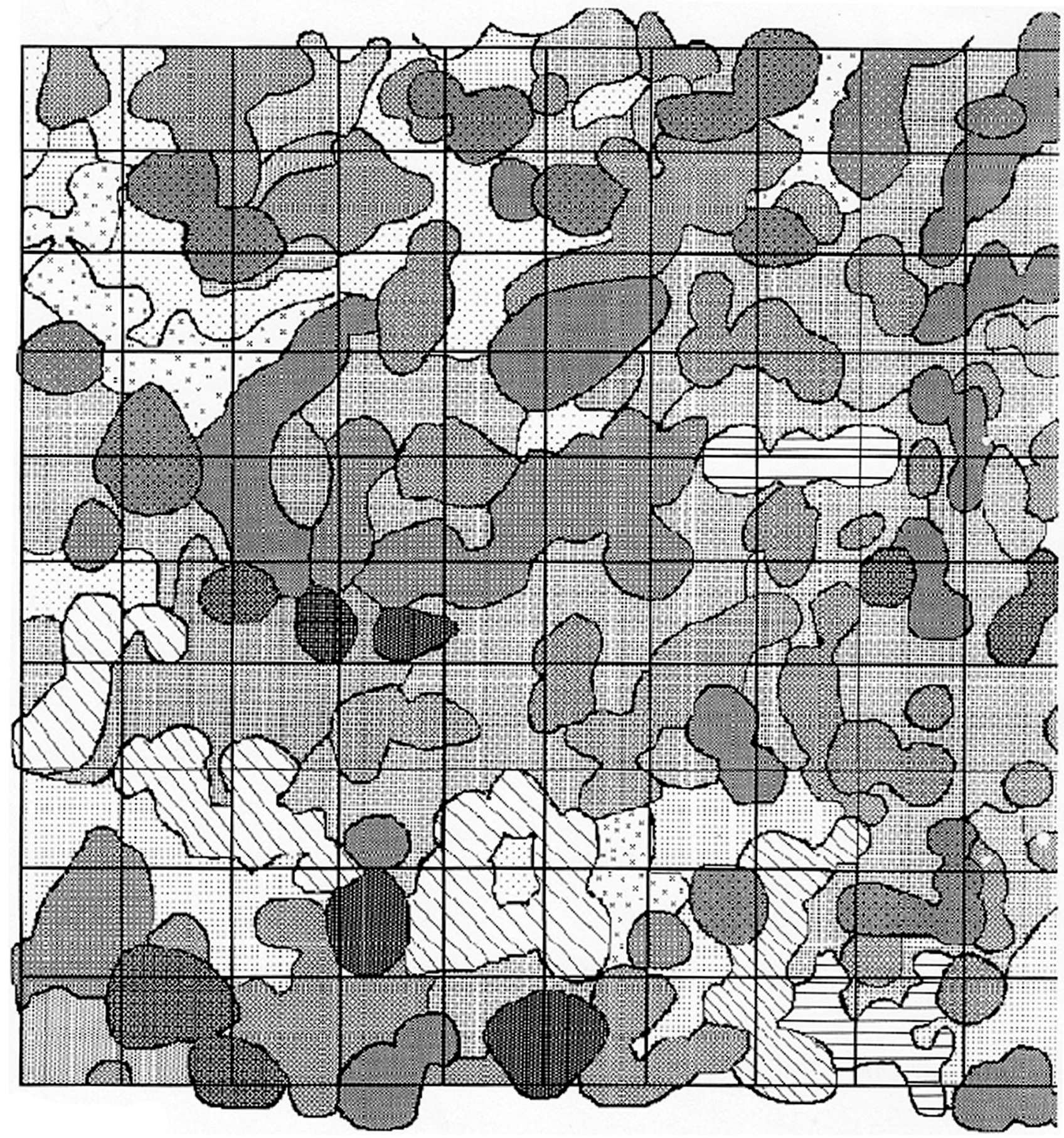

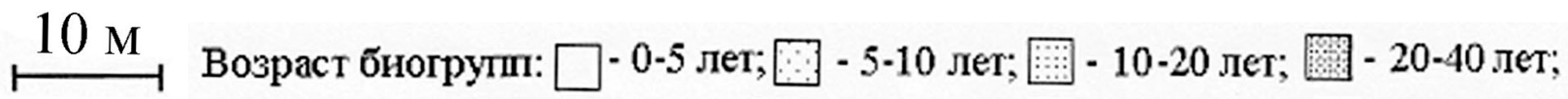

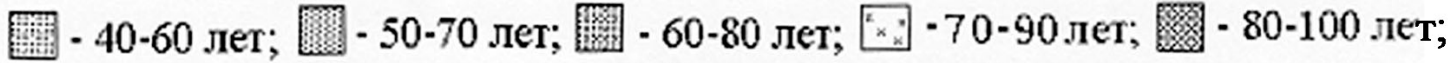

Е- 90-110 лет; - 100-120 лет; -

- 120-140 лет; - 140-160 лет;

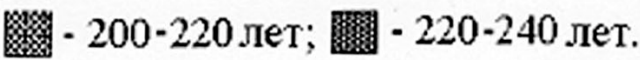

Рис. 2. Возрастная мозаичность неморального широколиственного леса

с доминированием Quercus robur и Tilia cordata (по результатам картирования 2001 г.)

Fig. 2. Mosaic of biogroups of multiple-aged trees in nemoral herb broad-leaved forest

with domination of Quercus robur and Tilia cordata (according to the results of mapping in 2001) 
Динамика ценопопуляций деревьев на постоянной пробной площади

(Кенчурское лесничество, кв. 104)

Table 1

Dynamic of tree populations on permanent sample plot (Kenchur forestry, quarter 104)

\begin{tabular}{|c|c|c|c|c|c|c|c|c|c|}
\hline \multirow[t]{2}{*}{ Виды } & \multicolumn{3}{|c|}{$\begin{array}{l}\text { Плотность взрослых } \\
\text { деревьев, особей/га }\end{array}$} & \multicolumn{3}{|c|}{$\begin{array}{c}\text { Общая плотность всех } \\
\text { особей, шт./га }\end{array}$} & \multicolumn{3}{|c|}{$\begin{array}{c}\text { Доля особей хорошей } \\
\text { жизненности от общей } \\
\text { численности, \% }\end{array}$} \\
\hline & 1976 г. & 1989 г. & $2001 \Gamma$. & 1976 г. & 1989 г. & $2001 \Gamma$. & 1976 г. & 1989 г. & 2001 г. \\
\hline 1. Quercus robur & 4 & 4 & 4 & 11 & 14 & 4 & 63,6 & 50,0 & 75,0 \\
\hline 2. Fraxinus excelsior & 94 & 129 & 222 & 911 & 981 & 442 & 84,0 & 81,1 & 9,3 \\
\hline 3. Tilia cordata & 240 & 244 & 192 & 1275 & 587 & 465 & 40,1 & 45,1 & 66,0 \\
\hline 4. Acer platanoides & 270 & 264 & 238 & 679 & 746 & 449 & 45,5 & 35,9 & 34,7 \\
\hline 5. Ulmus glabra & 76 & 63 & 150 & 633 & 654 & 438 & 47,2 & 46,6 & 16,7 \\
\hline 6. Populus tremula & 0 & 0 & 0 & 101 & 4 & 12 & 87,1 & 0 & 8,3 \\
\hline 7. Sorbus acuparia & 3 & 3 & 17 & 135 & 111 & 141 & 66,7 & 66,7 & 23,5 \\
\hline Всего & 687 & 707 & 823 & 3745 & 3097 & 1951 & & & \\
\hline
\end{tabular}

В целом тип популяции, в соответствии с классификациями Т. А. Работнова [13], А. А. Уранова и его учеников $[14,15]$, сохранился у дуба, липы, клена. Популяция дуба - нормальная фрагментарно-неполночленная: отсутствуют виргинильные, молодые генеративные и сенильные деревья; липы - старая нормальная полночленная. В 1989 г. в спектре липы появился дополнительный локальный максимум на молодых деревьях $\left(v+g_{1}\right)-18,6 \%$ от общей численности. Он по размерам даже несколько превзошел основной максимум на старых деревьях $\left(g_{3}+s\right.$ : $16,3 \%$ ). Как показали наши исследования, наличие двух максимумов - бимодальный спектр - типичен для деревьев толерантных стратегий [16], и это свидетельствует о переходе данной популяции в некое равновесное состояние. Молодой нормальной осталась популяция клена остролистного, во взрослой части которой преобладают молодые деревья $\left(v+g_{1}\right)$ : 26,3 и $24,8 \%$. Отсутствие второго максимума $\left(g_{3}+s\right)$ указывает на недостаточность истекшего срока наблюдений по сравнению с темпами его онтогенеза в условиях отсутствия рубок. В 1976 г. в популяции клена не было сенильных деревьев, а в 1989 г. они появились, что сделало ее не просто полночленной, а завершенной. Тип популяции ясеня не изменился: она осталась молодой нормальной незавершенной, так как не имеет зрелых и старых деревьев. Однако в начале наших наблюдений они были, но погибли во время ветровала (1980). Кроме того, молодые деревья ясеня часто страдают от поздних весенних заморозков (май, июнь) в связи с близостью исследуемого массива к северо-восточной границе ареала вида, что сказывается на жизненности и продолжительности жизни растений.
К 2001 г. в составе верхних ярусов наблюдаемого сообщества значительно возросло участие ясеня, подрост которого в связи с вывалом и последовавшим частичным осветлением активизировал свой рост. Наиболее сильные экземпляры его к этому времени достигли генеративного состояния. Число взрослых деревьев дуба осталось неизменным. Незначительные колебания численности произошли во взрослых фракциях липы и клена, заметно выросла доля вяза (см. табл. 1). Древостой (по численности) оказался представленным в соотношении 3(Д+Яс)2Лп3Ко2В. Малочисленный подрост дуба полностью погиб, снизилась жизненность особей ясеня: в составе его популяции доля особей хорошей жизненности не превысила 9,3 \% при исходной 84,0 \% (1976) и 81,0 \% (1989). Популяция вяза была в 1976 г. молодой нормальной (максимум на $v+g_{1}-10,4 \%$ ), полночленной. В 1989 г. она сохранила максимум на молодых деревьях (8,6 \%), но стала незавершенной: в ее составе отсутствовали старые генеративные и сенильные деревья. К 2001 г. его популяция вновь стала завершенной и вернулась к исходному типу: молодая нормальная полночленная. К 1989 г. популяция рябины из фрагментарно неполночленной, но завершенной (1976), стала молодой нормальной незавершенной, и такой осталась до конца наших наблюдений (2001). Популяция осины за весь срок наблюдений (1976-2001) оставалась инвазионной, в ее составе то резко снижалась плотность и жизненность молодых растений (со 101 до 4 шт./га), то увеличивалась (12 шт./га, 2001 г.).

За годы наблюдений фактически не изменился способ самоподдержания популяций: исключительно семенной у дуба, преимуще- 
ственно вегетативный - у липы, осины, рябины; преимущественно семенной - у ясеня и в равной мере семенной и вегетативный у клена остролистного и вяза.

Общая сомкнутость крон насаждения изменялась незначительно и сохранялась на уровне 0,8 , хотя в соотношении покрытий соподчиненных ярусов происходили значительные подвижки. Число возрастных биогрупп и их размеры также не оставались постоянными (рис. 3).
К началу наблюдений в сообществе присутствовали биогруппы одиннадцати классов возраста: самые взрослые достигали 200-220 лет. В конце мониторинга имелись деревья 12 классов возраста и, соответственно, Quercus robur и отдельные особи Tilia cordata достигли 220-240 лет (см. рис. 2). Изменения в горизонтальной структуре сообщества коснулись и количественного соотношения биогрупп разного размера (см. рис. 3).

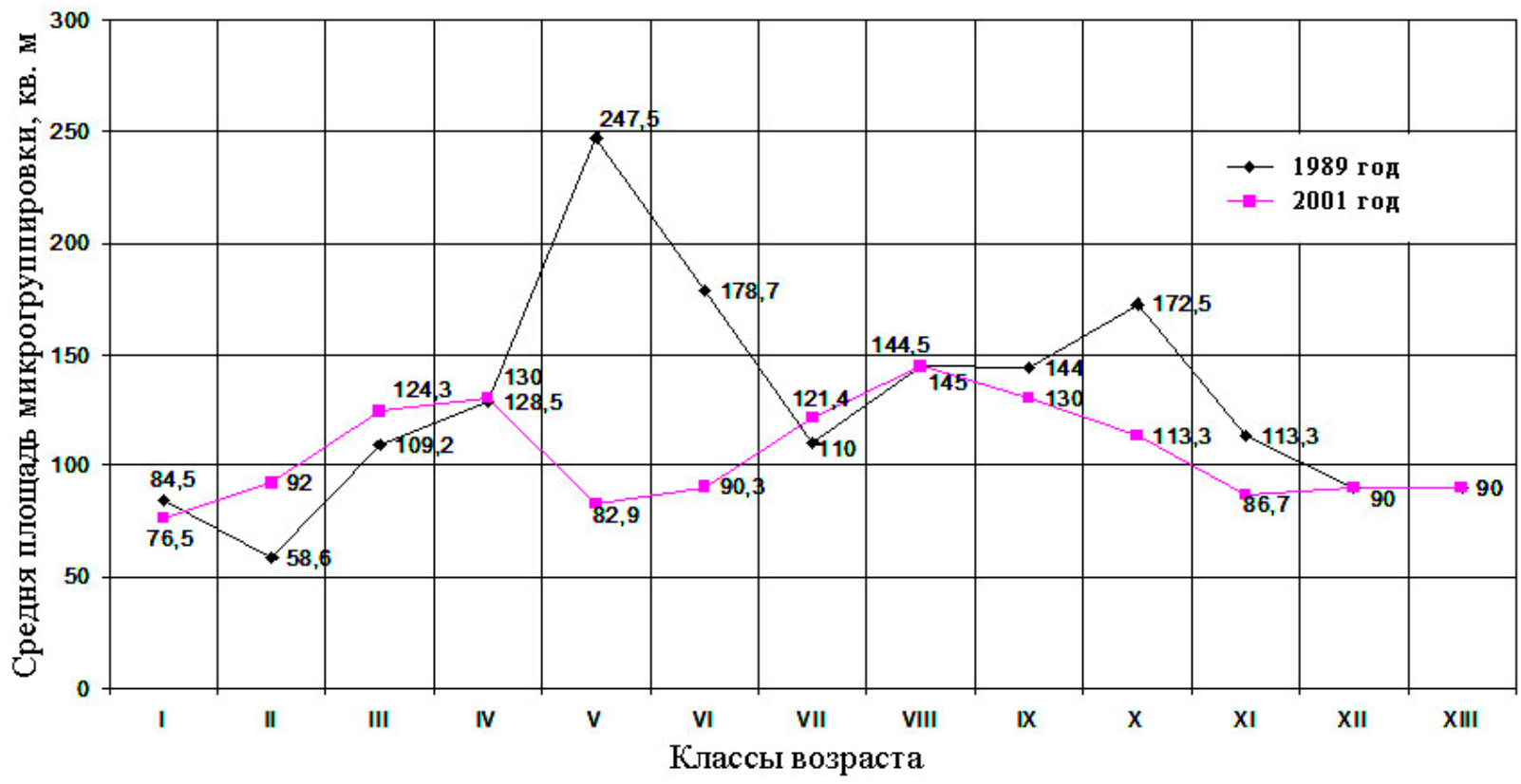

Рис. 3. Средние размеры биогрупп деревьев разного возраста (на основе анализа карт неморального широколиственного леса с доминированием Quercus robur и Tilia cordata в 1989 и 2001 гг.)

Fig. 3. Average size of biogroups of multiple-aged trees (based on the analysis of maps of broad-leaved forest with domination of Quercus robur and Tilia cordata in 1989 and 2001)

В 2001 г. общая площадь, занятая небольшими биогруппами (до $200 \mathrm{~m}^{2}$ ), составила

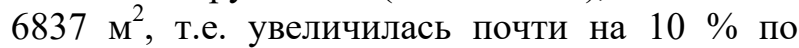
сравнению с 1989 г. (5880 м²). При этом средняя площадь одной маленькой микропруппировки за тот же период сократилась с $92 \mathrm{~m}^{2}$ до $80 \mathrm{~m}^{2}$, т.е. на $13 \%$. В целом в сообществе преобладают маленькие группировки; они принадлежат всем имеющимся в насаждении классам возраста (см. рис. 3).

Общая площадь, занятая биогруппами средних размеров (200-400 м²) в пределах пробной площади, напротив, уменьшилась (примерно на $4 \%$ ) так же, как и средние размеры каждой из них: с $260 \mathrm{~m}^{2}$ (1989) до 228 м $^{2}$ (2001), или на 24,6 \%. При этом микрогруппировки средних размеров в прошлом имелись практически во всех классах возраста, что обеспечивало непрерывный онтогенез почти всех видов деревьев вплоть до генеративного состояния. В 2001 г. возраст биогруппы средних размеров не превысил 140-160 лет (7-8 классы), что вызвало не- которую задержку развития светлолюбивых деревьев (Quercus robur, Fraxinus excelsior, Ulmus glabra, Populus tremula) и даже гибель их подроста. Именно недостатком света объясняется снижение жизненности прегенеративных деревьев этих видов (см. табл. 1). Среди них осина даже на начальных этапах онтогенеза является самой требовательной к свету $[17,18]$. Отсутствием достаточно больших окон объясняется инвазионный характер ее ценопопуляций, при котором ее подрост вегетативного происхождения регулярно появляется на пробной площади, периодически гибнет и заменяется новым, но поступательного развития его не происходит (см. табл. 1).

Биогруппы довольно большого размера

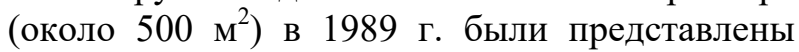
двумя возрастными кассами (4-м и 5-м), а в 2001 г. - только одним (3-м), что свидетельствует о постепенной гибели ослабленных деревьев в их составе и сокращении площади, занимаемой биогруппой, по мере ее взросления. 


\section{Заключение}

Исследование показало, что существующая горизонтальная структура (мозаичность) исследуемого сообщества обеспечивает надежное развитие только теневыносливых видов (Acer platanoides, Tilia cordata) или тех, подрост которых мирится с недостатком света на начальных этапах онтогенеза (Fraxinus excelsior, Ulmus glabra). Для видов, требовательных к свету на протяжении всего цикла развития (Quercus robur, Populus tremula), имеющаяся световая мозаика не подходит. Сопоставление возрастной мозаики с состоянием популяций деревьев, их плотностью, жизненностью позволяет сделать вывод о том, что горизонтальная структура изучаемого сообщества не вполне обеспечивает самоподдержание всех видов, в особенности светолюбивых. Наблюдаемые колебания численности популяций в большинстве случаев следует отнести к флуктуациям, которые свойственны для всех живых систем. В то же время малочисленность популяции дуба, медленное развитие и зачастую гибель его подроста делают положение этого вида в современных сообществах весьма уязвимым. В начале XX в., судя по данным литературы [19], популяции дуба в Инзенском массиве были более многочисленными, но сильно пострадали и продолжают испытывать отрицательное влияние от приисковых рубок.

Неполнота видового состава и невозможность его восстановления при существующей структуре сообщества позволяют характеризовать его как квазиклимаксовый, трансформация которого в климаксовый невозможна без вмешательства человека. Уменьшение размеров возрастной мозаичности препятствует формированию в будущем полночленных популяций всех потенциальных ценозообразователей.

\section{Библиографический список}

1. Популяционная диагностика и прогнозы развития заповедных лесных массивов (на примере Каневского заповедника) / О. В. Смирнова, Р. Р. Возняк, О. И. Евстигнеев, В. Н. Коротков, Н. Я. Носач, Р. В. Попадюк, В. К. Самойленко, Н. А. Торопова // Ботанический журнал. - 1991. - Т. 76. - № 6. - С. 68-79.

2. Рипа, С. И. Роль ветровально-почвенных комплексов в возобновлении древесных видов и в поддержании биологического разнообразия природных буковых и темнохвойно-буковых лесов Украинских Карпат / С. И. Рипа // Russian Journal of Ecosystem Ecology. - 2017. - Vol. 2 (2). - P. 1-33. DOI: 10.21685/2500-05782017-2-3.

3. Evstigneev, O. I. Pine forest succession on sandy ridges within outwash plain (sandur) in Nerussa-Desna Polesie / O. I. Evstigneev, V. N. Korotkov // Russian Journal of Ecosystem Ecology. - 2016. - Vol. 1 (3). - P. 1-18. DOI: $10.21685 / 2500-0578-2016-3-2$

4. Евстигнеев, О. И. Популяционная организация грабовых лесов Каневского заповедника / О. И. Евстигнеев, В. Н. Коротков, Л. В. Бакалына // Бюллетень Московского общества испытателей природы. Отдел биологический. - 1992. - Т. 97. - Вып. 2. - С. 81-89.

5. Евстигнеев, О. И. Ельники высокотравные - климаксные сообщества на низинных болотах Брянского полесья / О. И. Евстигнеев, М. В. Горнова // Russian Journal of Ecosystem Ecology. - 2017. - Vol. 2 (3). - P. 1-23. DOI 10.21685/2500-0578-2017-3-3.

6. Рыжков, О. В. Состояние и развитие дубрав Центральной лесостепи (на примере заповедников ЦентральноЧерноземного и «Лес на Ворскле») : автореф. дис. ... канд. биол. наук / Рыжков О. В. - Краснодар, 1996. - 22 с.

7. Лесные стационарные исследования: методы, результаты, перспективы. - Тула : Гриф и Ко, 2001. - 590 с.

8. Мониторинг сообществ на гарях и управление пожарами в заповедниках / отв. ред. Л. В. Кулешова. - М. : ВНИИприроды, 2002. - 276 с.

9. Булохов, А. Д. Эколого-флористическая классификация лесов Южного Нечерноземья России / А. Д. Булохов, А. И. Соломещ. - Брянск : Изд-во БГУ, 2003. - 359 с.

10. Заугольнова, Л. Б. Возрастные этапы в онтогенезе ясеня обыкновенного (Fraxinus excelsior L.) / Л. Б. Заугольнова // Вопросы морфогенеза цветковых растений и строения их популяций. - М. : Наука, 1968. C. 81-102.

11. Чистякова, А. А. Большой жизненный цикл Tilia cordata Mill. / А. А. Чистякова // Бюллетень Московского общества испытателей природы. Отдел биологический. - 1979. - Т. 84. - Вып. 1. - С. 85-98.

12. Evstigneev, O. I. Ontogenetic stages of trees: an overview / O. I. Evstigneev, V. N. Korotkov // Russian Journal of Ecosystem Ecology. - 2016. - Vol. 1 (2). - P. 1-31. DOI: 10.21685/2500-0578-2016-2-1.

13. Работнов, Т. А. Изучение ценотических популяций в целях выяснения «стратегии жизни» видов растений / Т. А. Работнов // Бюллетень Московского общества испытателей природы. Отдел биологический. - 1975. Т. 80. - Вып. 2. - С. 5-17.

14. Уранов, А. А. Классификация и основные черты развития популяций многолетних растений / А. А. Уранов, О. В. Смирнова // Бюллетень Московского общества испытателей природы. Отдел биологический. - 1969. Т. 74. - Вып. 1. - С. 119-134.

15. Смирнова, О. В. Ценопопуляции растений (основные понятия и структура) / О. В. Смирнова, Л. Б. Заугольнова, И. М. Ермакова и др. - М. : Наука, 1976. - 216 с. 
16. Чистякова, А. А. Возрастная мозаичность восточноевропейских широколиственных лесов / А. А. Чистякова // Лесоведение. - 1996. - № 4. - С. 29-38.

17. Евстигнеев, О. И. Отношение лиственных деревьев к свету / О. И. Евстигнеев // Биологические науки. 1991. - № 8. - С. 20-29.

18. Евстигнеев, О. И. Механизмы поддержания биологического разнообразия лесных биогеоценозов : автореф. дис. ... д-ра биол. наук / Евстигнеев О. И. - Н. Новгород, 2010. - 48 с.

19. Никулин, А. К вопросу о роли липы в лесу и хозяйстве / А. Никулин // Лесной журнал. - 1916. - Вып. 6. C. 708-720.

\section{References}

20. Популяционная диагностика и прогнозы развития заповедных лесных массивов (на примере Каневского заповедника) / О. В. Смирнова, Р. Р. Возняк, О. И. Евстигнеев, В. Н. Коротков, Н. Я. Носач, Р. В. Попадюк, В. К. Самойленко, Н. А. Торопова // Ботанический журнал. - 1991. - Т. 76. - № 6. - С. 68-79.

21. Рипа, С. И. Роль ветровально-почвенных комплексов в возобновлении древесных видов и в поддержании биологического разнообразия природных буковых и темнохвойно-буковых лесов Украинских Карпат / С. И. Рипа // Russian Journal of Ecosystem Ecology. - 2017. - Vol. 2 (2). - P. 1-33. DOI: 10.21685/2500-05782017-2-3.

22. Evstigneev, O. I. Pine forest succession on sandy ridges within outwash plain (sandur) in Nerussa-Desna Polesie / O. I. Evstigneev, V. N. Korotkov // Russian Journal of Ecosystem Ecology. - 2016. - Vol. 1 (3). - P. 1-18. DOI: $10.21685 / 2500-0578-2016-3-2$.

23. Евстигнеев, О. И. Популяционная организация грабовых лесов Каневского заповедника / О. И. Евстигнеев, В. Н. Коротков, Л. В. Бакалына // Бюллетень Московского общества испытателей природы. Отдел биологический. - 1992. - Т. 97. - Вып. 2. - С. 81-89.

24. Евстигнеев, О. И. Ельники высокотравные - климаксные сообщества на низинных болотах Брянского полесья / О. И. Евстигнеев, М. В. Горнова // Russian Journal of Ecosystem Ecology. - 2017. - Vol. 2 (3). - P. 1-23. DOI 10.21685/2500-0578-2017-3-3.

25. Рыжков, О. В. Состояние и развитие дубрав Центральной лесостепи (на примере заповедников ЦентральноЧерноземного и «Лес на Ворскле») : автореф. дис. ... канд. биол. наук / Рыжков О. В. - Краснодар, 1996. - 22 с.

26. Лесные стационарные исследования: методы, результаты, перспективы. - Тула : Гриф и Ко, 2001. - 590 с.

27. Мониторинг сообществ на гарях и управление пожарами в заповедниках / отв. ред. Л. В. Кулешова. - М. : ВНИИприроды, 2002. - 276 с.

28. Булохов, А. Д. Эколого-флористическая классификация лесов Южного Нечерноземья России / А. Д. Булохов, А. И. Соломещ. - Брянск : Изд-во БГУ, 2003. - 359 с.

29. Заугольнова, Л. Б. Возрастные этапы в онтогенезе ясеня обыкновенного (Fraxinus excelsior L.) / Л. Б. Заугольнова // Вопросы морфогенеза цветковых растений и строения их популяций. - М. : Наука, 1968. C. 81-102.

30. Чистякова, А. А. Большой жизненный цикл Tilia cordata Mill. / А. А. Чистякова // Бюллетень Московского общества испытателей природы. Отдел биологический. - 1979. - Т. 84. - Вып. 1. - С. 85-98.

31. Evstigneev, O. I. Ontogenetic stages of trees: an overview / O. I. Evstigneev, V. N. Korotkov // Russian Journal of Ecosystem Ecology. - 2016. - Vol. 1 (2). - P. 1-31. DOI: 10.21685/2500-0578-2016-2-1.

32. Работнов, Т. А. Изучение ценотических популяций в целях выяснения «стратегии жизни» видов растений / Т. А. Работнов // Бюллетень Московского общества испытателей природы. Отдел биологический. - 1975. T. 80. - Вып. 2. - С. 5-17.

33. Уранов, А. А. Классификация и основные черты развития популяций многолетних растений / А. А. Уранов, О. В. Смирнова // Бюллетень Московского общества испытателей природы. Отдел биологический. - 1969. Т. 74. - Вып. 1. - С. 119-134.

34. Смирнова, О. В. Ценопопуляции растений (основные понятия и структура) / О. В. Смирнова, Л. Б. Заугольнова, И. М. Ермакова и др. - М. : Наука, 1976. - 216 с.

35. Чистякова, А. А. Возрастная мозаичность восточноевропейских широколиственных лесов / А. А. Чистякова // Лесоведение. - 1996. - № 4. - С. 29-38.

36. Евстигнеев, О. И. Отношение лиственных деревьев к свету / О. И. Евстигнеев // Биологические науки. 1991. - № 8. - С. 20-29.

37. Евстигнеев, О. И. Механизмы поддержания биологического разнообразия лесных биогеоценозов : автореф. дис. ... д-ра биол. наук / Евстигнеев О. И. - Н. Новгород, 2010. - 48 с.

38. Никулин, А. К вопросу о роли липы в лесу и хозяйстве / А. Никулин // Лесной журнал. - 1916. - Вып. 6. C. 708-720.

\section{References}

1. Smirnova O. V., Voznyak R. R., Evstigneev O. I., Korotkov V. N., Nosach N. Ya., Popadyuk R. V., Samoylenko V. K., Toropova N. A. Botanicheskiy zhurnal [Botanical journal]. 1991, vol. 76, no. 6, pp. 68-79. 
2. Ripa S. I. Russian Journal of Ecosystem Ecology. 2017, vol. 2 (2), pp. 1-33. DOI: 10.21685/2500-0578-2017-2-3.

3. Evstigneev O. I., Korotkov V. N. Russian Journal of Ecosystem Ecology. 2016, vol. 1 (3), pp. 1-18. DOI: $10.21685 / 2500-0578-2016-3-2$.

4. Evstigneev O. I., Korotkov V. N., Bakalyna L. V. Byulleten' Moskovskogo obshchestva ispytateley prirody. Otdel biologi-cheskiy [Bulletin of Moscow Society of Naturalists. Biology section]. 1992, vol. 97, iss. 2, pp. 81-89.

5. Evstigneev O. I., Gornova M. V. Russian Journal of Ecosystem Ecology. 2017, vol. 2 (3), pp. 1-23. DOI 10.21685/2500-0578-2017-3-3.

6. Ryzhkov O. V. Sostoyanie i razvitie dubrav Tsentral'noy lesostepi (na primere zapovednikov Tsentral'noChernozemnogo $i$ «Les na Vorskle»): avtoref. dis. kand. biol. nauk [State and development of oak forests in the Central forest steppe (on the example of reserves in the Central black soil regions and "Forest on Vorskla"): author's abstract of thesis by the Candidate of Biological science]. Krasnodar, 1996, $22 \mathrm{p}$.

7. Lesnye statsionarnye issledovaniya: metody, rezul'taty, perspektivy [Forest stationary research: methods, results, prospects]. Tula: Grif i Ko, 2001, 590 p.

8. Monitoring soobshchestv na garyakh i upravlenie pozharami v zapovednikakh [Monitoring communities at fire-sites and managing fires in reserves]. Ed. by L. V. Kuleshov. Moscow: VNIIprirody, 2002, 276 p.

9. Bulokhov A. D., Solomeshch., A. I. Ekologo-floristicheskaya klassifikatsiya lesov Yuzhnogo Nechernozem'ya Rossii [Ecological and floristic classification of forests in the Southern non-black soil regions of Russia]. Bryansk: Izd-vo BGU, 2003, $359 \mathrm{p}$.

10. Zaugol'nova L. B. Voprosy morfogeneza tsvetkovykh rasteniy i stroeniya ikh populyatsiy [Issues of flowering plants morphogenesis and structure of their populations]. Moscow: Nauka, 1968, pp. 81-102.

11. Chistyakova A. A. Byulleten' Moskovskogo obshchestva ispytateley prirody. Otdel biologicheskiy [Bulletin of Moscow Society of Naturalists. Biology section]. 1979, vol. 84, iss. 1, pp. 85-98.

12. Evstigneev O. I., Korotkov V. N. Russian Journal of Ecosystem Ecology. 2016, vol. 1 (2), pp. 1-31. DOI: $10.21685 / 2500-0578-2016-2-1$.

13. Rabotnov T. A. Byulleten' Moskovskogo obshchestva ispytateley prirody. Otdel biologicheskiy [Bulletin of Moscow Society of Naturalists. Biology section]. 1975, vol. 80, iss. 2, pp. 5-17.

14. Uranov A. A., Smirnova O. V. Byulleten' Moskovskogo obshchestva ispytateley prirody. Otdel biologicheskiy [Bulletin of Moscow Society of Naturalists. Biology section]. 1969, vol. 74, iss. 1, pp. 119-134.

15. Smirnova O. V., Zaugol'nova L. B., Ermakova I. M. et al. Tsenopopulyatsii rasteniy (osnovnye ponyatiya i struktura) [Cenopopulation of plants (basic concepts and structure)]. Moscow: Nauka, 1976, $216 \mathrm{p}$.

16. Chistyakova A. A. Lesovedenie [Forest science]. 1996, no. 4, pp. 29-38.

17. Evstigneev O. I. Biologicheskie nauki [Biological sciences]. 1991, no. 8, pp. 20-29.

18. Evstigneev O. I. Mekhanizmy podderzhaniya biologicheskogo raznoobraziya lesnykh biogeotsenozov: avtoref. dis. d-ra biol. nauk [Mechanisms for maintaining the biological diversity of forest biogeocenoses: author's abstract of thesis by the Doctor of Biological science]. Nizhny Novgorod, 2010, 48 p.

19. Nikulin A. Lesnoy zhurnal [Forest journal]. 1916, iss. 6, pp. 708-720. 